\title{
ASSESSMENT OF HEAVY METALS POLLUTION IN GROUNDWATER AND COW'S MILK IN UPPER EGYPT
}

\author{
HAZEM A. AAMER ${ }^{1}$; DALIA M. HASSAN ${ }^{2}$ and SABER KOTB ${ }^{2}$ \\ ${ }^{1}$ Animal Hygiene Department, Faculty of Veterinary Medicine, Sohag University. Egypt. \\ ${ }^{2}$ Animal Hygiene Department, Faculty of Veterinary Medicine, Assiut University. Egypt.
}

Received: 29 February 2016 ; Accepted: 9 March 2016

\begin{abstract}
The present work deals with the evaluation of heavy metals pollution in raw cow's milk and groundwater in Upper Egypt. So, a total of 102 milk and ground water samples were collected from three Governorates in Upper Egypt, namely, Assiut, Sohag and Qena. Concentrations of lead (Pb), Cadmium (Cd), Iron ( $\mathrm{Fe})$ and Manganese (Mn) in the digested water and milk samples were determined by Buck model 210 VGP atomic absorption spectrophotometer with flame atomization. Our data showed that the average mean of lead, Iron and cadmium in collected water and milk samples were $(0.195 \mathrm{ppm}$ and $0.075 \mathrm{ppm}),(0.00040 \mathrm{ppm}$ and 0.00026 ppm) and (3.949 ppm and 0.869ppm), respectively. However, we could not detect Manganese either in milk or water samples. Furthermore, Statistical analysis of data showed that there was a significant correlation $(\mathrm{p}<$ 0.05) between heavy metal pollution in milk and that of correspondent examined groundwater samples.
\end{abstract}

Key words: Heavy metals, cow, milk, groundwater, pollution.

\section{INTRODUCTION}

The environmental pollution with heavy metals is an issue of global dignified concern and wherefore pollution of food chain is fetching further significance in view of its detrimental aspect in human health and nutrition (Pilarczyk et al., 2013 and Jalilian and Saber, 2015). Heavy metals pollution is an ecumenical hazard to the environment as they are widely distributed in the earth's crust, air, water and food chain (Matthew et al., 2002 and Szkoda et al., 2013B).

There is no doubt that water may act as a source of infection and toxicity among domestic animals. Drinking of polluted water by toxic heavy metals have been responsible for health problems in dairy farms and human beings (Rajaganapathy et al., 2011 and Mohod and Dhote, 2013). However, water used in the dairy farms either for drinking of livestock, washing of udder and utensils as well as that used for washing of the stable must be free from the toxic heavy metals.

An adequate supply of clean, fresh drinking water is widely considered essential for optimal cow health and maximum milk production (Radostitis et al.,

Corresponding author: Dr. Saber Kotb E-mail address: saberkotb@yahoo.com

Present address: Animal Hygiene Department, Faculty of Veterinary Medicine, Assiut University. Egypt.
2007; Beede, 2009 and Awasthi et al., 2012). The increment of heavy metals pollution in the ecosystem may be attributed to use of agricultural pesticides and related chemicals, unhygienic weed out wastes and diffusion of sewage quagmire (López-Alonso et al., 2003; Srikanth et al., 2004; Miranda et al., 2007; Chiroma et al., 2007 and Tona et al., 2013).

Milk is an essential diet for children as well as for adults due to its protein and mineral contents, contamination of these products is a major public health problem in many countries (Inam and Somer, 2000; Pilarczyk et al., 2013). Milk polluted with heavy metals is considered a vehicle for transmission of illness among consumers, especially in developing countries where food hygiene is still under-way due to lack of food hygienists, modern diagnostic methods, beside some environmental conditions and financial difficulties (EL atrash and Atoweir, 2014).

If lactating cows are exposed to high quantities of toxic metals, such as cadmium and lead, these metals disturb different metabolic activities as well as health of children (González-Weller et al., 2006; Vromman et al., 2008 and Cai et al., 2009). Enormous exposure of heavy metals such as cadmium, lead, iron and mercury is pernicious for plants, animals and human beings (Llobet et al., 2003; Malhat et al., 2012 and Mohod and Dhote, 2013). 
Estimation of the residual concentrations of heavy metals in milk could be a significant indicator of the hygienic status of the milk, as well as the degree of pollution of the environment in which the milk was produced (Licata et al., 2004 and Gonzalez-Montana et al., 2012).

Due to growing heavy metals pollution threatening human and animal health, therefore the main goal of this study was to assess the status of drinking water quality in Upper Egypt and its impact on cow's milk pollution.

\section{MATERIALS and METHODS}

\section{Source of specimens:}

\subsection{Animal housing:}

This study was conducted in 51 dairy cow's houses during the period from January to June, 2015. Each animal house associated with owner's houses in 3 different villages that equally distributed in three Governorates in Upper Egypt, namely Assiut, Sohag and Qena.

\section{Sampling:}

A total of 102 samples were taken as 51 milk and 51 water samples (34 samples from each Governorate). Each sample was taken under strict hygienic conditions and labeled to indicate type, date, time...etc, and then carried with a minimum of delay for chemical examination.

\subsection{Water samples:}

Fifty-one water samples were collected from the examined animal houses. The source of samples was groundwater in the three Governorates (one sample from each house). Each water sample was collected in clean dry plastic bottles previously rinsed by nitric acid fitted tightly with ground glass stopper (according to the recommendation of APHA, 2005). Before collection of samples, thoroughly cleaning of the tap nozzles of driven pumps was done, then water was run for 3-4 min to rinse any accumulated dust and dirt.

\subsection{Milk samples:}

Firstly, the teat apices were cleaned, then the first stream of quarter was discarded, and about $20 \mathrm{ml}$ of milk was drawn from each quarter into a sterile 250 $\mathrm{ml}$ capacity glass bottle. Milk sampling was done according to the recommendation of National Mastitis Council (1999).

\section{Preparations of samples:}

3.1. Glasswares were washed before use with distilled water, soaked in nitric acid $(30 \%)$, then rinsed in distilled water and air dried. All digestion tubes were identified for examination.

3.2. Water samples were digested by using a mixture of concentrated nitric and perchloric acids according to (Chau et al., 1979). Five milliliter of each sample was transferred to a digestion flask where it was treated with $5 \mathrm{ml}$ of nitric and perchloric acids mixture (HNO3: HCLO4 = 4:1 v/v). The samples were left to be stand for the cold digestion overnight, and then were heated on a hot plate (model 1030-RuMO 100) at $70^{\circ} \mathrm{C}$ till disappearance of the brown fumes of $\mathrm{NO} 3$ and the sample become clear. After cooling, each sample was diluted to $25 \mathrm{ml}$ with bi-distilled water and filtered through ashless filter paper (Whatman paper). The digested samples were kept refrigerated in $50 \mathrm{ml}$ propylene bottles till analysis.

\subsection{Milk samples}

Milk samples were processed for wet digestion where $1 \mathrm{ml}$ of each sample was digested by $5 \mathrm{ml}$ of concentrated nitric acid (HNO3) (Riedel-de Haen $\left.{ }^{\circledR}\right)$ and $5 \mathrm{ml}$ of concentrated perchloric acid (HCIO4). The samples were left to be stand for the cold digestion overnight, and then were heated on a hot plate (model 1030-RuMO 100) at $70^{\circ} \mathrm{C}$ till disappearance of the brown fumes of $\mathrm{NO} 3$ and the sample become clear. After cooling, each sample was diluted to $25 \mathrm{ml}$ with bi-distilled water and filtered through ashless filter paper (Whatman paper). The digested samples were quantitatively transferred into $50 \mathrm{ml}$ flask, made up to the mark with distilled water and stored in $50 \mathrm{ml}$ propylene bottles as described by Debeca and Mckenzie, 1992 and Tsoumbaris and Tsoukali-Papadopulou (1994).

\section{Measurement of heavy metals in milk and water samples: \\ Concentrations of lead $(\mathrm{Pb})$, Cadmium $(\mathrm{Cd})$,} Manganese $(\mathrm{Mn})$ and Iron $(\mathrm{Fe})$ in the digested water and milk samples were determined by Buck model 210 VGP atomic absorption spectrophotometer with flame atomization. Buck Scientific Inc. East Norwalk, CT (USA), in the lab of Faculty of Science, Assiut University, Egypt.

\section{Statistical analysis}

Analysis of variance of data was computed using the General Linear Models (GLM) Procedure of SAS software version 9 (SAS, 2009). The mean of heavy metals concentrations and standard error were measured in milk and water and comparison between the milk and water was done using t-test. Pearson Correlation was made to measure the correlation between the estimated variables. P-value was considered statistically significant when $p<0.05$. 


\section{RESULTS}

Table 1: Heavy Metals levels in the examined cow's milk (ppm)

\begin{tabular}{|c|c|c|c|c|c|}
\hline \multirow{2}{*}{ Metal } & \multirow{2}{*}{ Governorates } & \multicolumn{3}{|c|}{ Milk } & \multirow{2}{*}{$\begin{array}{c}\text { Maximum Permissible } \\
\text { Limit (ppm) }\end{array}$} \\
\hline & & Minimum & Maximum & Mean \pm SE & \\
\hline \multirow{4}{*}{$\begin{array}{l}\text { Lead } \\
(\mathbf{P b})\end{array}$} & Assiut & 0.013 & 0.143 & $0.067 \pm 0.043$ & \multirow{4}{*}{$\begin{array}{c}0.02 \\
\text { according to Codex Alimentarius } \\
\text { commission (2007) and } \\
\text { According to IDF Standard } \\
(1979)\end{array}$} \\
\hline & Sohag & 0.001 & 0.220 & $0.084 \pm 0.055$ & \\
\hline & Qena & 0.02 & 0.134 & $0.073 \pm 0.035$ & \\
\hline & Total houses & 0.02 & 0.220 & $0.075 \pm 0.044$ & \\
\hline \multirow{4}{*}{$\begin{array}{l}\text { Cadmium } \\
\text { (Cd) }\end{array}$} & Assiut & 0.0001 & 0.0006 & $0.00027 \pm 0.0001$ & \multirow{4}{*}{$\begin{array}{c}0.0026 \\
\text { According to IDF Standard } \\
(1979)\end{array}$} \\
\hline & Sohag & 0.00010 & 0.003 & $0.00031 \pm .0 .0008$ & \\
\hline & Qena & 0.00011 & 0.003 & $0.00035 \pm 0.0009$ & \\
\hline & Total houses & 0.00010 & 0.003 & $0.00026 \pm 0.00011$ & \\
\hline \multirow{4}{*}{$\begin{array}{l}\text { Iron } \\
(\mathrm{Fe})\end{array}$} & Assiut & 0.508 & 1.31 & $0.840 \pm 0.247$ & \multirow{5}{*}{$\begin{array}{l}\qquad 0.037 \\
\text { According to IDF Standard (1979) }\end{array}$} \\
\hline & Sohag & 0.571 & 1.374 & $0.911 \pm 0.321$ & \\
\hline & Qena & 0.522 & 1.103 & $0.855 \pm 0.238$ & \\
\hline & Total houses & 0.571 & 1.374 & $0.869 \pm 0.265$ & \\
\hline \multirow{4}{*}{$\begin{array}{l}\text { Manganese } \\
\text { (Mn) }\end{array}$} & Assiut & 0 & 0 & $0.000 \pm 0.000$ & \\
\hline & Sohag & 0 & 0 & $0.000 \pm 0.000$ & \multirow{3}{*}{$\begin{array}{c}\text { According to } \\
\text { Wenlock et al. (1979) }\end{array}$} \\
\hline & Qena & 0 & 0 & $0.000 \pm 0.000$ & \\
\hline & Total houses & 0 & 0 & $0.000 \pm 0.000$ & \\
\hline
\end{tabular}


Table 2: Heavy Metals levels in the examined groundwater samples (ppm)

\begin{tabular}{|c|c|c|c|c|c|}
\hline \multirow{2}{*}{$\begin{array}{l}\text { Examined } \\
\text { Metal }\end{array}$} & \multirow{2}{*}{ Governorates } & \multicolumn{3}{|c|}{ Groundwater } & \multirow{2}{*}{$\begin{array}{c}\text { Maximum Permissible } \\
\text { Limit according to WHO, } \\
2011(\mathrm{ppm})\end{array}$} \\
\hline & & Minimum & Maximum & Mean $\pm \mathrm{SE}$ & \\
\hline \multirow{4}{*}{$\begin{array}{l}\text { Lead } \\
(\mathbf{P b})\end{array}$} & Assiut & 0.144 & 0.261 & $0.187 \pm 0.036$ & \multirow{4}{*}{0.01} \\
\hline & Sohag & $0-137$ & 0.324 & $0.230 \pm 0.068$ & \\
\hline & Qena & 0.087 & 0.341 & $0.168 \pm 0.083$ & \\
\hline & Total houses & 0.144 & 0.341 & $0.195 \pm 0.07$ & \\
\hline \multirow{4}{*}{$\begin{array}{l}\text { Cadmium } \\
\text { (Cd) }\end{array}$} & Assiut & 0.0001 & 0.0006 & $0.00031 \pm 0.00017$ & \multirow{4}{*}{0.003} \\
\hline & Sohag & 0.0003 & 0.0006 & $0.00042 \pm 0.00015$ & \\
\hline & Qena & 0.0003 & 0.0008 & $0.00049 \pm 0.00026$ & \\
\hline & Total houses & 0.0001 & 0.0008 & $0.00040 \pm 0.00021$ & \\
\hline \multirow{4}{*}{$\begin{array}{l}\text { Iron } \\
(\mathrm{Fe})\end{array}$} & Assiut & 1.833 & 5.052 & $3.456 \pm 1.162$ & \multirow{5}{*}{0.3} \\
\hline & Sohag & 2.457 & 6.301 & $4.417 \pm 1.244$ & \\
\hline & Qena & 2.08 & 6.333 & $3.975 \pm 1.725$ & \\
\hline & Total Farms & 2.457 & 6.333 & $3.949 \pm 1.416$ & \\
\hline \multirow{4}{*}{$\begin{array}{c}\text { Manganese } \\
\text { (Mn) }\end{array}$} & Assiut & 0 & 0 & $0.000 \pm 0.000$ & \\
\hline & Sohag & 0 & 0 & $0.000 \pm 0.000$ & \multirow{3}{*}{0.1} \\
\hline & Qena & 0 & 0 & $0.000 \pm 0.000$ & \\
\hline & Total houses & 0 & 0 & $0.000 \pm 0.000$ & \\
\hline
\end{tabular}

Table 3: Statistical analysis of heavy metal in milk and water samples

\begin{tabular}{ccc}
\hline & \multicolumn{2}{c}{ Examined samples } \\
\cline { 2 - 3 } Metal & Milk & water \\
\hline Lead & $0.075 \pm 0.044^{*}$ & $0.195 \pm 0.07^{*}$ \\
\hline Cadmium & $\mathbf{0 . 0 0 0 2 6} \pm \mathbf{0 . 0 0 0 1 1 ^ { * }}$ & $\mathbf{0 . 0 0 0 4 0 \pm 0 . 0 0 0 2 1 ^ { * }}$ \\
\hline Iron & $\mathbf{0 . 8 6 9} \pm \mathbf{0 . 2 6 5 ^ { * }}$ & $\mathbf{3 . 9 4 9} \pm \mathbf{1 . 4 1 6 ^ { * }}$ \\
\hline Manganese & Not detected & Not detected
\end{tabular}

\footnotetext{
${ }^{*}:$ Means with superscripts are significantly related at $\mathrm{P}<0.05$.
} 


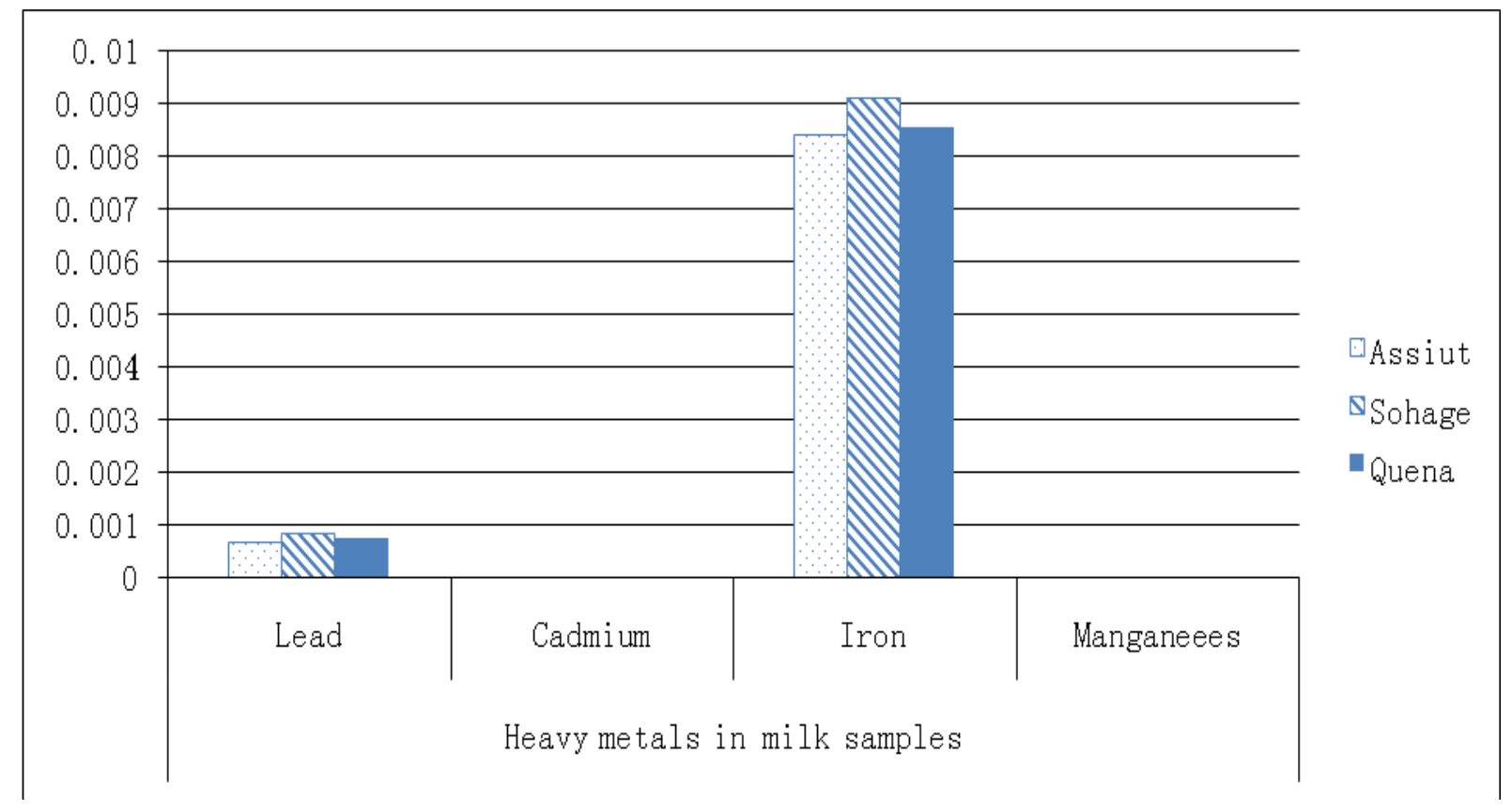

Fig. 1: Diagram of heavy metals concentration in cow's milk samples of the different three governorates.

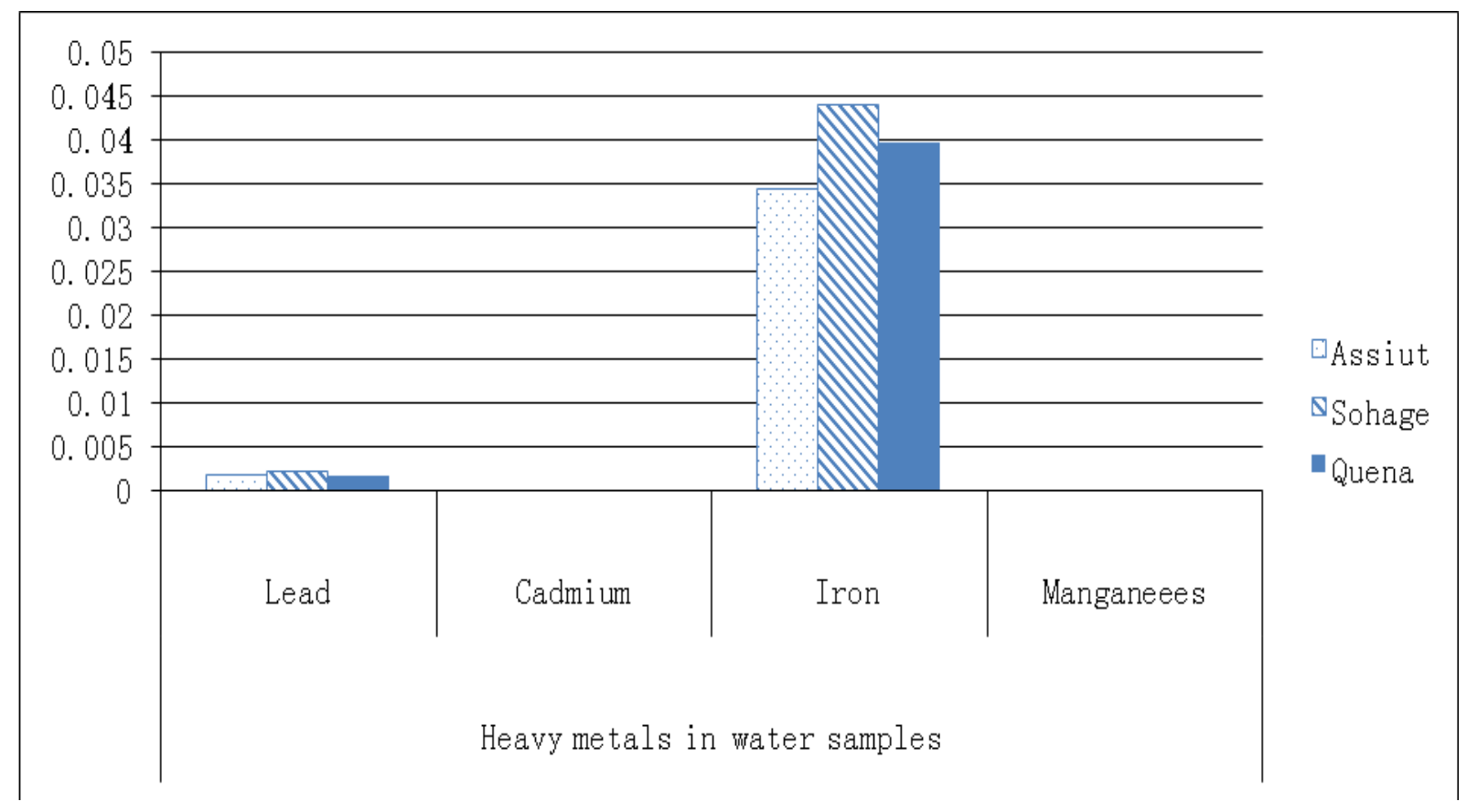

Fig. 2: Diagram of heavy metals concentration in ground water samples of the different three Governorates 


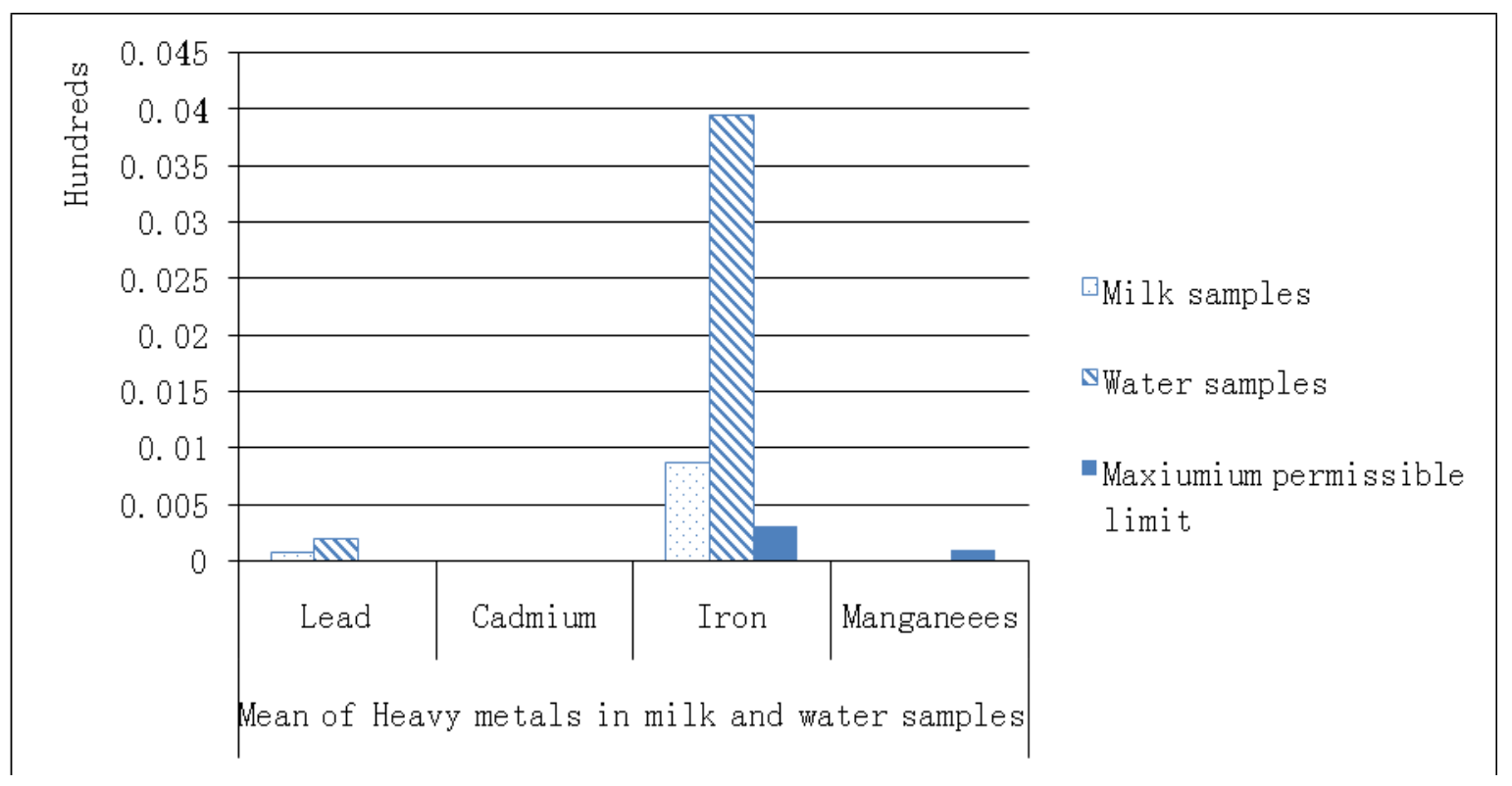

Fig. 3: Diagram of Mean heavy metals concentration in ground water and cow's milk samples

\section{DISCUSSION}

\section{Heavy metals in milk}

Excretion of milk from bovine mammary glands can convoy abundant of xenobiotic elements, which constitute a health hazard risk for the consumer. Measurement of the residual concentrations of metals in milk could be one of the most important steps in determining the hygienic status of the milk and the extent of environment pollution in which the milk was produced (Licata et al., 2004; GonzálezMontaña et al., 2012 and Pilarczyk et al., 2013).

The concentration of different examined heavy metals in milk samples is given in table 1 and figure 1.

The results of table (1) and figure (1) showed that there was variation between the mean level of Lead concentration of milk samples at different Governorates, where the highest concentration found in Sohag Governorate (0.084 ppm) followed by Qena (0.073 ppm) and Assiut (0.067 ppm), respectively. The same table showed that the mean concentration of lead of all examined milk samples from all different houses was $0.075 \pm 0.044 \mathrm{ppm}$. This finding more or less in agreement with the results of Pavlovic et al. (2004); Gabryszuk et al. (2010); Bilandžić et al. (2011) and Malhat et al. (2012)

Concerning Cadmium concentration in milk samples, we found that the mean of cadmium contents in the examined milk samples of Assiut, Sohag and Qena Governorates were 0.00027 ppm, $0.00031 \mathrm{ppm}$ and $0.00035 \mathrm{ppm}$, respectively.
However, the mean content of cadmium in all milk samples was $0.00026 \mathrm{ppm}$.

This result was less than that detected with Malhat et al. (2012), who found that Cd ranged from 0.200 to $0.288 \mathrm{ppm}$ in milk samples.

In regarding to Iron, from our study, we noticed that the mean content of lead in examined milk samples was $0.869 \mathrm{ppm}$. This finding was lower than that detected by Malhat et al. (2012) who found that the mean $\mathrm{Fe}$ concentration in the milk samples varied from 10.95 to $16.38 \mathrm{ppm}$. Also, our result was lower than Haldar et al. (2003) and Santos et al. (2015) who reported Fe in cow's milk varied from 3.97 to $4.19 \mathrm{ppm}$.

Concerning Manganese concentration in milk samples, we failed to detect it in all examined milk samples from different examined animal houses. This result was coincided with Lante et al. (2006). On the other hand, our result was disagreed with Haldar et al. (2003) and Santos et al. (2015) who found $\mathrm{Mn}$ in cow's milk with the range of 1.60 to $1.69 \mathrm{ppm}$.

The maximum permissible levels of heavy metals recommended by international dairy federation standard (IDF Standard 1979) are $0.037 \mathrm{ppm}$ for Fe, $0.02 \mathrm{ppm}$ for $\mathrm{Pb}$, and $0.0026 \mathrm{ppm}$ for $\mathrm{Cd}$. According to Codex Alimentarius Commission (2007) the maximum residues limit for $\mathrm{Pb}$ in milk is $0.02 \mathrm{ppm}$.

The average concentration of the Lead and Iron in milk samples was compared with the maximum permissible limits. Our results showed that all milk samples collected from the different Governorates 
containing Lead and Iron with concentration higher than those recommended for milk by IDF standard, 1979. Lead is an environmental pollutant which is toxic to humans and animals (Cai et al., 2009). As well as $\mathrm{Pb}$ is non-biodegradable, and their accumulation in the environment raises agricultural and public health concerns (Olsson et al., 2005 and De Vries et al., 2007). Unfortunately, the lead content in the milk of cows was higher than the permissible concentration of $0.02 \mathrm{ppm}$ in the raw. The higher content of $\mathrm{Pb}$ in milk may be attributed to industrial air pollution in this area especially all houses located at a traffic ways, the use of contaminated feed, and mineral supplements as well as water supply of bad hygienic quality (Antunovic et al., 2005; Rodrigue et al., 2009; Abdulkhaliq et al., 2012 and Santos et al., 2015).

Iron play a crucial role in protecting the body against the negative effects of toxic free radicals (Santos et al., 2015). As well as iron promotes development of oxidized flavor in milk and milk products. They also catalyze oxidation of ascorbic acid and influence lipase activity (Mondal et al., 2015). However, Fe can represent a problem in dairy technology because of its catalytic effect on oxidation of lipids with development of unpleasant smell, bounding preferably proteins and membrane lipoproteins of milk fatty globule (Lante et al., 2006). Iron overdoses manifestation in human is dehydration, hypovolemia, evidence of hepatic necrosis (elevated alanine transaminase and aspartate transaminase activities) and liver failure (Greentree and Hall, 1995 and Hillman, 1995).

\section{2- Heavy metals in water}

Water is the most important nutrient for lactating dairy cattle. It is required in a larger quantity than all other nutrients combined. Without an adequate clean, fresh supply of water every day, milk production will be severely compromised.

From the mentioned data (table 2 and figure 2), we noticed that the average mean of Lead content in water samples was $0.195 \mathrm{ppm}$ with the highest and lowest mean contents were found in water samples collected from Sohag houses $(0.230 \mathrm{ppm})$ and Qena houses $(0.168 \mathrm{ppm})$, respectively.

All the examined water samples contained lead concentration above the levels permitted by WHO (2011). The main sources of lead contamination are industrial discharges from smelters, battery manufacturing units, run off from contaminated land areas, atmospheric fall out and sewage effluents. The levels of $\mathrm{Pb}$ from this study were lower than study reported by Nassef et al. (2006) and Wongsasuluk et al. (2014) and higher than those reported by Boateng et al. (2015).
Source of lead in drinking water is mainly through the corrosion of lead-bearing pipe materials which located adjacent to sewage effluent and water canals and drains used to irrigate agricultural land as in our examined houses (Javed et al., 2009; Brown et al., 2011; Triantafyllidou and Edwards, 2012; Edwards, 2014 and Masters and Edwards, 2015).

Maximum allowable level of Lead in drinking water is $0.01 \mathrm{ppm}$ according to WHO (2011). But today no level of lead is considered to be safe (Dettwyler, 2000) as it produces a strong negative effect on human and animal health (Bhat and Moy, 1997). Today everyone is exposed to environmental lead in the form of industrial wastes, leaded gasoline and other anthropogenic sources (Khillare et al., 2004 and Al-Masri et al., 2006). Air pollution is very common in the big cities because of the vehicles burn gasoline containing lead. It is thought that lead is responsible for number of deaths (Oroian et al., 2007).

The obtained data given intable (2) and figure (2) showed that the cadmium contents in Assiut, Sohag and Qena governorates were $0.00031 \mathrm{ppm}, 0.00042$ ppm and $0.00049 \mathrm{ppm}$, respectivily with overall mean content of $0.00040 \mathrm{ppm}$ and this result was not coincided with Boateng et al. (2015) and Gimba et al. (2015).

Cadmium concentrations in palatable water are up to $0.01 \mathrm{ppm}$ considered as permissible limit (WHO, 2011). Groundwater barely contains huge amount of cadmium except if it is polluted by industrial wastewater, tailings from mining or leakage from precarious waste sites (ATSDR, 2008).

It is fortunate that the content of Cadmium in milk and water samples in all governorates was under maximum permissible limit. However, further studies should be conducted to assess heavy metal concentration in animal tissues and organs as well as other environmental samples as soil and air. It has been found that cadmium has not a single physiological function within the human body. Therefore, attention has been diverted to its biohazardous potential. Once cadmium is absorbed, it accumulates in the body even throughout the life (Bernard, 2008). Even low concentration of cadmium can adversely affect the number of metabolic processes in animal body (Bernard, 2004 and Nordberg et al., 2007). Cadmium intoxication can lead to kidney, bone and pulmonary damages (Godt et al., 2006). Cadmium toxicity affects various organs such as the liver, lung, testis and hematopoietic system in animals (Kocak and Akc, 2006).

An acute toxicity symptom generally includes abdominal and muscular cramps, headache, 
overtiredness, shock and ultimately death (USAF, 1990). Cadmium is also absorbed in significant quantities from cigarette smokes which ultimately cause toxic effects on both human and animal health. The deleterious effects are especially on kidneys, liver and vascular system but most undesirable effects have been seen on reproductive tissues and developing embryos (Thompson and Bannigan, 2008).

Also, we found from the data present in table (2) and figure (2) that the iron content in water samples ranged from $1.833 \mathrm{ppm}$ to $6.33 \mathrm{ppm}$ with the mean value of $3.949 \mathrm{ppm}$ in all examined water samples. Our result was more or less coincided with data reported by Ansa-Asare et al. (2009); Boateng et al. (2015), Gimba et al. (2015) and Masters and Edwards (2015).

The maximum permissible limit reported by WHO (2011) is $0.3 \mathrm{ppm}$ for iron, all examined water samples were observed to be above the maximum permissible limit set by the world health organization(WHO) for drinking water. This indicates that the local mineral deposit in the studied area may have high levels of iron.

Chronic consumption of water with iron overload may results in fatigue, weight loss, joint pains and ultimately heart disease, liver problems and diabetes (US-CDC 2011).

Contrastingly, the obtained data given in table (2) and figure (2) showed that there is no manganese in all examined water samples and this result was not coincided with Boateng et al. (2015) and Gimba et al. (2015).

Obviously, Heavy metals established naturally in the ecosystem with large variations in concentrations (Adeosun et al., 2015). Most metals reach water streams originate from industrial, municipal and urban run-offs which can be deleterious to our life (Tolcin, 2011). Overwhelm civilization of industrialization could be the cause for an enhanced level of heavy metals in our waterways ( Njar and Al-Doush, 2012). Heavy metals pervade in water as colloidal, particulate and dissolved phases (AdepojuBello et al., 2009) with their existence in water bodies being either of natural origin (e.g. eroded minerals within sediments) or of anthropogenic origin (i.e. solid waste disposal, industrial or domestic effluents) (Marcovecchio et al., 2007).

\section{Correlation analysis:}

Statistical analysis of variable (table, 3) between heavy metals pollution of milk and that of water indicated that there is a significant positive relationship $(\mathrm{P}<0.05)$ between heavy metal pollution of milk and those in water samples. This mean that the main source of milk polluted with heavy metals is mainly originate from water contamination. Our result was coincided with (Rajaganapathy et al., 2011; Mohod and Dhote, 2013).

\section{CONCLUSION}

From our obtained data, it can be concluded that lead and iron were more than the maximum permissible limit either in milk or groundwater. However, Cadmium less than the acceptable limits. Our data confirmed the high pollution of ground water sources and hence, they are not suitable for consumption without any prior treatment. Also, there is need for caution as they have the potential to bio-concentrate some of these heavy metals in food chain over time. So, we suggested that milk and ground water in Upper Egypt should be continuous precisely monitoring for other heavy metals pollution to obviate the risk of impact of heavy metals on human and animal health.

\section{ACKNOWLEDGMENT}

This research was supported by Department of Animal Hygiene, Faculty of Veterinary Medicine, Assiut University and Sohag University.

\section{REFERENCES}

Abdulkhaliq, A.; Swaileh, K.M.; Hussein, R.M. and Matani, M. (2012): Levels of metals (Cd, Pb, $\mathrm{Cu}$ and $\mathrm{Fe}$ ) in cow's milk, dairy products and hen's eggs fromthe West Bank, Palestine. International Food Research Journal 19 (3):1089-1094.

Adeosun, F.; Akinyemi, A.; Idowu, A.; Taiwo, I.; Omoike, A. and Ayorinde, B. (2015): The effects of heavy metals concentration on some commercial fish in Ogun River, Opeji, Ogun State, Nigeria. Afr. J. Environ. Sci. Technol.Vol 9(4): 365- 370.

Adepoju-Bello, A.A.; Ojomolade, O.O.; Ayoola, G.A. and Coker, H.A.B (2009): Quantitative analysis of some toxic metals in domestic water obtained from Lagos metropolis. The Nig. J. Pharm. 42 (1):57-60.

Al-Masri, M.S.; Al-Kharfan, K. and Al-Shamali, K. (2006): Speciation of $\mathrm{Pb}, \mathrm{Cu}$ and $\mathrm{Zn}$ determined by sequential extraction for identification of air pollution sources in Syria. Atmosph. Environmt.; 40: 753-761

American Public Health Association (APHA) (2005): Standard Methods for the Examination of Water and Wastewater. $21^{\text {th }}$ Ed., Washington, DC.

Ansa-Asare, O.D.: Darko, H.F. and Asante, K.A. (2009): Groundwater quality assessment of 
Akatsi, Adidome and Ho districts in the Volta region of Ghana. Desalination. 248:446-452

Antunovic, Z.; Bogut, I.; Sensic, D.; Katic, M. and Mijic, P. (2005): Concentrations of selected toxic elements (cadmium, lead, mercury and arsenic) in ewe milk in dependence on lactation stage. Czech Journal of Food Science 50: 369-375

ATSDR (Agency for Toxic Substances and Disease Registry), (2008): Cadmium Toxicity Where is Cadmium Found? Case Studies in Environmental Medicine (CSEM).Prepared for US Department of Health and Human Services, Public Health Service, Agency for Toxic Substances and Disease Registry. Atlanta, GA.

Awasthi, V.; Bahman, S.; Thakur, L.K.; Singh, S.K. and Dua, A. and Ganguly, S. (2012): Contaminants in milk and impact of heating: an assessment study. Indian journal of public health 56, 95-99.

Beede, D.K. (2009): Solving bad water problems for thirsty cows. Proc. WDMC Reno NV: 11-13: 217-227.

Bernard, A. (2004): Renal dysfunction induced by cadmium: biomarkers ofcritical effects. Biometals. 17: 519-23.

Bernard, A. (2008): Cadmium and its adverse effects on human health. Indian. J.Med. Res. 128: 557-564.

Bhat, R.V. and Moy, G.G. (1997): Monitoring and assessment of dietary exposure to chemical contaminants. World Health Statistics Quarterly. 50(1-2): 132-149.

Bilandžić, N.; Dokić, M.; Sedak, M.; Božica, S.; Varenina, I. and Knežević, Z. (2011): Trace element levels in raw milk from northern and southern regions of Croatia. Food Chemistry; 127(1): 63-66.

Boateng, T.K.; Opoku, F.; Acquaah, S.O. and Akoto, $O$. (2015): Pollution evaluation, sources and risk assessment of heavy metals in hand-dug wells from Ejisu-Juaben Municipality, Ghana. Environ Syst Res (2015) 4:18.

Brown, M.J.; Raymond, J.; Homa, D.; Kennedy, C. and Sinks, T. (2011): Association between children's blood lead levels, lead service lines, and water disinfection, Washington, DC, 1998-2006. Environ. Res. 111, 67.

Cai, Q.; Long, M.L.; Zhu, M.; Zhou, Q.Z.; Zhang, L. and Liu, J. (2009): Food chain transfer of cadmium and lead to cattle in a lead-zinc smelter in Guizhou, China. Environmental Pollution, 157(11): 3078-3082.

Chau, Y.K.; Wong, P.T.S. and Bengert, G.A. (1979): Determination of tetra-alkyl-lead compounds in water, sediments, and fish samples. Anal Chem. 51: 186-188.

Chiroma, T.M.; Abdulkarim, B.I. and Kefas, H.M. (2007): The Impact of Pesticide Application on Heavy Metal $(\mathrm{Cd}, \mathrm{Pb}$ and $\mathrm{Cu})$ Levels in
Spinach. Leo. Electron. J. Pract. Tech., 11: 117-122.

Codex Alimentarius Commission (2007): Codex standard for food grade salt. CX STAN 1501985, Amend, 3-2007. 1-7. In: World Health Organization/Food and Agriculture Organization of the United Nations, Rome.

Debeca, R.W. and McKenzie, A.D. (1992): Total Diet Study of Lead and Cadmium in Food Composites; Preliminary Investigations", Journal of AOAC International, 75 (3), 386394

Dettwyler, K.A. (2000): Breastfeeding beyond three years in the United States: Method, Theory, and Implications for Public Health." Meetings of the American Anthropological Association, San Francisco, California, November 18

De Vries, W.; Römkens, P.F. and Schütze, G. (2007): Critical soil concentrations of cadmium, lead, and mercury in view of health effects on humans and animals. Reviews of Environmental Contamination and Toxicology. 191:91-130.

Edwards, M. (2014): Fetal death and reduced birth rates associated with exposure to leadcontaminated drinking water. Environ. Sci. Technol. 48, 739 .

El atrash, S. and Atoweir, N. (2014): Determination of lead and cadmium in raw cow's milk by graphite furnace atomic absorption spectroscopy. International Journal of Chemical Sciences, 12(1): 92-100.

Gabryszuk, M.; Stoniewski, K.; Metera, E. and Sakowski, T. (2010): Content of mineral elements in milk and hair of cows from organic farms. Journal of Elementology. 15(2): 259-267.

Gimba, C.E.: Ndukwe, G.I.; Paul, E.D.; Habila, J.D. and Madak, L.A. (2015): Heavy Metals (Cd, $\mathrm{Cu}, \mathrm{Fe}, \mathrm{Mn}$ and $\mathrm{Zn}$,) Assessment of Groundwater, In Kaltungo LGA, Gombe State, Nigeria. International Journal of Science and Technology. 4 (2): 49-56.

Godt, J.; Scheidig, F.; Grosse-Siestrup, C.; Esche, $V$.; Brandenburg, P. and Groneberg, R.A. (2006): The toxicity of cadmium and resulting hazardsfor human health. J. Occup. Med. Toxicol., 1: 22-23.

González-Montaña, J.R.; Senís, E.; Gutiérrez, A. and Prieto, F. (2012): Cadmium and lead in bovine milk in the mining area of the Caudal River (Spain) Environmental Monitoring and Assessment, 184(7): 4029-4034.

González-Weller, D.; Karlsson, L.; Caballero, A.; Hernández, F.; Gutiérrez, A.; GonzálezIglesias, T. (2006): Lead and cadmium in meat and meat products consumed by the population in Tenerife Island, Spain. Food Additives and Contaminants, 23(8): 757-763. 
Greentree, W.F. and Hall, J.O. (1995): Iron toxicosis. In: Bonagura JD, ed. Kirk's current therapy XII small animal practice. Philadelphia, Pa: WB Saunders Co, 240-242.

Haldar, S.; Ghosh, T.K. and Pal, N. (2003): Effects of trace elements supplementation in commercially reared dairy cows of different lactation in relation to mineral metabolism. Indian Journal of Animal Science 73 (4): 437-443.

Hillman, R.S. (1995): Hematopoietic agents: growth factors, minerals, and vitamins. In: Hardman JG, Limbird LE, Molinoff PB, eds. Goodman $\& 9^{\text {th }}$ ed. New York City, NY: McGraw-Hill, 1311-1340.

IDF Standard. (1979): International Dairy Federation Bulletin, Chemical residues in milk and milk products. I.D.F. Document, 133.

Inam, R. and Somer, G. (2000): A direct method for the determination of selenium and lead in cow's milk by differential pulse stripping voltammetry. Food Chem. 69: 345-350.

Jalilian, H. and Saber, A.R. (2015): Evaluation on the level of lead $(\mathrm{Pb})$ heavy metals in milk of cows in farms of Ardebil province, Iran. IJBPAS, April, 4(4): 2318-2323.

Javed, I.; Jan, I.U.; Muhammad, F.; Rahman, Z.U.; Khan, M.Z.; Aslam, B. and Sultan, J.I. (2009): Heavy metal residues in the milk of cattle and goats during winter season. Bull. Environ. Contam. Toxicol., 82: 616-620.

Khillare, P.S.; Balachandran, S. and Meena, B. (2004): Spatial and temporal variation of heavy metals in atmospheric aerosols of Delhi. Environ. Monit. Assess. 90, 1-21.

Kocak, M. and Akc, E. (2006): The effects of chronic cadmium toxicity on the hemostatic system. Pathophy. Haemo. Thromb., 35: 411416.

Lante, G.; Lomolino, G.; Cagnin, M. and Spttoli, P. (2006): Content andcharacterization of minerals in milk and in Crescenza and Squaacquerne Italian fresh cheese by ICPOES. Food Control. J.,17: 229-233.

Licata, P.; Trombetta, D.; Cristani, M.; Giofrè, F.; Martino, D.; Calò, $M$. and Naccari, $F$. (2004): Levels of "toxic" and "essential" metals in samples of bovine milk from various dairy farms in Calabria, Italy. Environ. Int. 30(1):1-6.

Llobet, J.M.; Falco, G.; Casas, C.; Teixido, A. and Domingo, J.L. (2003): Concentrations of arsenic, cadmium, mercury and lead in common foods and estimated daily intake by children, adolescents, adult and seniors of Catalonia, Spain. J. Agric. Food Chem., 51: 838-842.

López-Alonso, M.; Prieto Montaña, F.; Miranda, M.; Castillo, C.; Hernández, J. and Benedito, J.L. (2003): Cadmium and Lead accumulation in cattle in NW Spain. Vet. Human Toxicol. 45: 128-130.

Malhat, F.; Hagag, M.; Saber, A. and Fayz, A.E. (2012): Contamination of cow's milk by heavy metal in Egypt. Bulletin of environmental contamination and toxicology. 88: 611-613.

Marcovecchio, J.E.; Botte, S.E. and Freije, R.H. (2007): Heavy Metals, Major Metals, Trace Elements. In: Handbook of Water Analysis. L.M. Nollet, (Ed.). $2^{\text {nd }}$ Ed. London: CRC Press.: 275-311.

Masters, S. and Edwards, M. (2015): Increased Lead in Water Associated with Iron Corrosion: Environmental engineering science, 32(5): 361-369.

Matthew, M.M.; Henke, R. and Atwood, A. (2002): Effectiveness of commercial heavy Metal chelators with new insights for the future in chelate design. J. Hazar. Mater.: 92(2): 129142.

Miranda, M.L.; Kim, D.; Hull, A.P.; Paul, C.J. and Galeano, M.A. (2007): Changes in blood lead levels associated with use of chloramines in water treatment systems. Environ Health Perspect., 115: 221-225.

Mohod, C.V. and Dhote, J. (2013): Review of heavy metals in drinking water and their effect. International Journal of Innovative Research in Science, Engineering and Technology 2(7): 2992-2996.

Mondal, M.; Pyne, S.K.; Samanta, G. and Roy, R. (2015): Studies on trace minerals in cow and buffalo milk in Red Lateritic Zone of West Bengal. Int. J. Bio-res. Env. Agril. Sci.1(1): 36-38.

Nassef, M.;Hannigan, R.; EL Sayed, K.A. and ElTahawy, M.S. (2006): Determination of Some Heavy Metals In the Environment of Sadat Industrial City. Proceedings of the $2^{\text {nd }}$ Environmental Physics Conference, 18-22 Feb. 2006, Alexandria, Egypt.

National Mastitis Council (NMC) (1999): Laboratory Handbook on Bovine Mastitis. NMC Inc., Madison, WI.

Njar, D.R. and Al- Doush, I. (2012): Mercury content in skin-lightening creams and potential hazards to the health of Saudi women. J. Toxicol. Environ. Health. 51(2):123-130.

Nordberg, G.; Nogawa, K.; Nordberg, M. and Friberg, L. (2007): Cadmium. In:Nordberg G.; Fowler B.; Nordberg M.; Friberg L. (eds) Handbook on Toxicology of Metals. Academic, New York, pp 65-78.

Olsson, I.M.; Eriksson, J.; Oborn, I.; Skerfving, S. and Oskarsson, A. (2005): Cadmium in food production systems: a health risk for sensitive population groups. Ambio. 34(4-5): 344-351.

Oroian, I.; Paulette, L.; Rusu, T. and Dumitras, A. (2007): The effects of environmental factors 
on the quality of human life and ecosystems in Romania. J. Food Agri. Environ. 5 (1): 248-256.

Pavlovic, I.; Sikiric, M.; Havranek, J.L.; Plavljanic, N. and Brajenovic, N. (2004): Lead and cadmium levels in raw cow's milk from an industrialized Croatian region determined by electro-thermal atomic absorption spectrometry. Czech J. Anim. Sci., 49(4): 164-168.

Pilarczyk, R.; Wójcik, J.; Czerniak, P.; Sablik, P.; Pilarczyk, B. and Tomza-Marciniak, A. (2013): Concentrations of toxic heavy metals and trace elements in raw milk of Simmental and Holstein-Friesian cows from organic farm. Environ. Monit. Assess.,185: 83838392.

Radostitis, O.; GAY, CC. and Hinchcliff, K.W. (2007): Veterinary medicine: A textbook of the diseases of cattle, horses, sheep, pigs, and goats. $10^{\text {th }}$ ed. Philadelphia: Saunders, pp673762.

Rajaganapathy, V.; Xavier, F.; Sreekumar, D. and Mandal, P.K. (2011): Heavy Metal Contamination in Soil, Water and Fodder and their presence in Livestock and Products: A Review. Journal of Environmental Science and Technology,4:234-249.

Rodrígue, L.; Ruiz, E. and Alonso-Azcárate, J. (2009): Heavy Metal Distribution And Chemical Speciation In Tailings And Soils Around $\mathrm{A} \mathrm{Pb}-\mathrm{Zn}$ Mine In Spain. Journal of Environmental Management, 90, 1106-1116.

Santos, C.B.G.; Oliveira, A.P.; Martins, D.L.; Oliveira, J.C.; Pedro, F.G.G. and Villa, R.D. (2015): Determination of the concentrations of essential and toxic metals in UHT milk produced in Mato Grosso State, Brazil. International Food Research Journal 22(3): 981-986.

SAS (2009): User`s guide version, 9.2, SAS Institute Inc., Cary, NC, USA.

Srikanth, R.; Rao, A.M.; Kumar, C.H.S. and Khanum, A. (2004): Lead, cadmium, nickel, and zinc contamination of ground water around Hussain Sagar lake, Hyderabad, India. Bull. Environ. Contam. Toxicol.,50 (1): 138143.

Szkoda, J.; Zmudzki, J.; Nawrocka, A. and Kmiecik, A. (2013B): Concentrations of toxic elements in tissues of slaughtered animals and cow's milk- a five year study. B. Vet. I. Pulawy. 57, 529-533.

Thompson, J. and Bannigan, J. (2008): Cadmium: Toxic effects on the reproductive system and the embryo. Reprod. Toxicol., 25(3): 304315.

Tolcin, A.C. (2011): Mineral Commodity Summaries 2009: Zinc. United States Geological Survey. WHO contributors, (2007). "The impact of zinc supplementation on childhood mortality and severe morbidity". World Health Organization. World Health Organisation, WHO (2007). "The impact of zinc supplementation on childhood mortality and severe morbidity". World Health Organization.

Tona, G.O.; Adetunji, V.O.; Ameen, S.A. and Ibikunle, A.O. (2013): Evaluation of Lead and Cadmium Heavy Metal Residues in Milk and Milk Products Sold in Ogbomoso, Southwestern Nigeria. Pakistan Journal of Nutrition 12 (2): 168-171.

Triantafyllidou, S. and Edwards, M. (2012): Lead $(\mathrm{Pb})$ in tap water and in blood: implications for lead exposure in the United States. Crit. Rev. Environ. Sci. Technol. 42:1297.

Tsoumbaris, P. and Tsoukali-Papadopoulou, $H$. (1994): Heavy metals in common foodstuff: quantitative analysis. Bull. Environ. Contam. Toxicol. Jul; 53(1): 61-6.

United States Centre for Disease Control (UNC). (2011): Iron overload and Hemochromatosis. Centre for Disease control. March 28.

USAF (1990): Cadmium. In: Installation Restoration Program Toxicology Guide, Vol. 5. Harry G. Armstrong Aerospace Medical Research Laboratory, Wright Patterson AFB, OH.

Vromman, V.; Saegerman, C.; Pussemier, L.; Huyghebaert, A.; De Temmerman, L. and Pizzolon, J.C. (2008): Cadmium in the food chain near non-ferrous metal production sites. Food Additives and Contaminants: Part A, 25(3): 293-301.

Wenlock, R.W.; Buss, D.H. and Dixon, E.J. (1979): Trace Nutrients. 2-Manganese in British Foods. British Journal of Nutrition. 41: 25361

Wongsasuluk, P.; Chotpantarat, S.; Siriwong, W. and Robson, M. (2014): Heavy metal contamination and human health risk assessment in drinking water from shallow groundwater wells in an agricultural area in UbonRatchathani province, Thailand. Environ. Geochem. Health. 36:169-182

WHO (World Health Organization). (2011): Guidelines for drinking-water quality, $4^{\text {th }} \mathrm{Ed}$. Switzerland, Geneva. 


\section{تقييم التلوث بالمعادن الثقيلة في المياه الجوفية وحليب الابقار في صعيد مصر \\ حازم أحمد عامر ، داليا محمد على ، صابر قطب \\ E-mail: $\underline{\text { saberkotb@yahoo.com } \quad \text { Assiut University web-site: www.aun.edu.eg }}$}

تناولت هذه الدر اسة تقييم تلوث المعادن الثقيلة في المياه الجوفية وحليب البقر الخام في صعيد مصر .لذلك تم تجميع اجمالي عدد 102

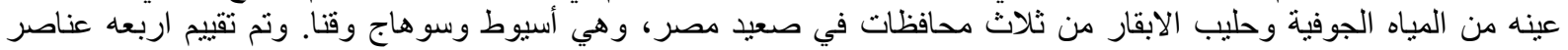

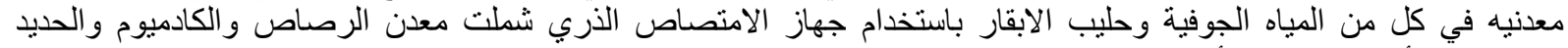

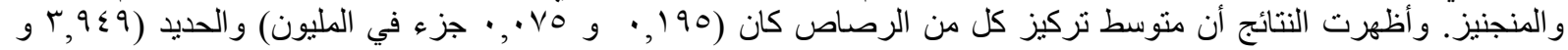

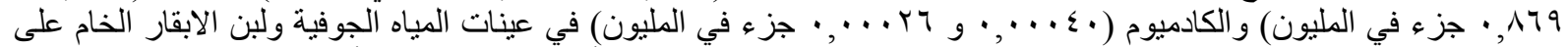

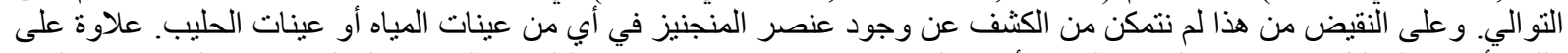

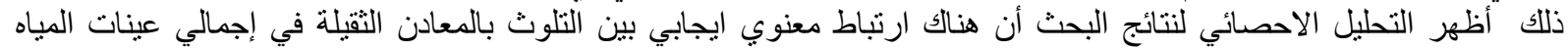
و الحليب المختبره.

الكلمات الكاشفة: المعادن الثقيلة ، التلوث ، المياه الجوفية ، الألبان ، الأبقار. 